Cadernos de Semiótica Aplicada

Vol. 4.n.2, dezembro de 2006

\title{
A PUBLICIDADE NA INTIMIDADE
}

\section{THE ADVERTISING IN THE INTIMACY}

Milton Chamarelli Filho

UFA - Universidade Federal do Acre

\begin{abstract}
Resumo: $O$ presente artigo discute algumas estratégias que a publicidade utiliza para persuadir um público cada vez mais diferenciado. Observamos, então, formas icônicas e verbais, que permitem a identificação do consumidor com o produto anunciado, a partir da construção de uma intimidade que passa pela imagem do produto e pela linguagem que a publicidade utiliza.
\end{abstract}

Palavras-chave: publicidade; discurso; mídia; persuasão.

Abstract: The present article argues some strategies that the advertising uses to persuade a public more and more differentiated. We observe, then, verbal and icônics forms, that allow the identification of the consumer with the announced product, from the construction of a intimacy that passes for the image of the product and for the language that the advertising uses.

Keywords: advertising; discourse; media; persuasion.

\section{Considerações iniciais}

Ao situar-se no âmbito das linguagens que povoam o nosso universo midiático, a publicidade $^{1}$ utiliza cada vez mais estratégias, no intuito de obter uma identificação do

\footnotetext{
${ }^{1}$ Optamos pelo uso termo publicidade, que nos parece ser o mais usual, e o que implica menos conotações ideológicas. Ao lado deste, encontram-se outros, tais como: reclame, propaganda, anúncio, comercial etc. Cada um com uma interpretação específica.
} 
público para com os produtos anunciados, estabelecendo, a partir daí, uma relação, que se deve tornar familiar e, muitas vezes, quase íntima, aos olhos do consumidor.

Se a finalidade da publicidade é a de conduzir o possível comprador ao consumo do produto, quais serão, então, as formas pelas quais ela se fará chegar a um interlocutor (leitor, telespectador, etc.), ou, ainda, torná-lo sensível a sua mensagem, já que cada vez mais há um público diferenciado, a quem ela visa conquistar?

$\mathrm{Na}$ emaranhada rede de relações entre publicidade e público, o fator econômico, por exemplo, não é o único determinante para responder sobre o comportamento de compra do consumidor (ROCHA, 1988, p. 3), Em verdade, as variáveis que interferem na compra do produto são muitas: das psicológicas às sociais (ROCHA, 1988, p. 10). O que torna, então, a mensagem publicitária eficaz? Ou, como sua mensagem é construída, a fim de que ela possa, antes de qualquer coisa, chamar a atenção para si própria?

Embora a publicidade institucionalizada seja conhecida desde o século XIX, foi no início do século XX, com a quebra da bolsa de Nova York, que o mercado se viu entre a superprodução de produtos e a falência, daí a importância de se "oferecerem" produtos e a de se criarem demandas. Frente à criação de demandas, nasce a linguagem publicitária, pretendendo diminuir a distância entre o produto anunciado e o público.

Mas como a publicidade, a princípio, tornou sua mensagem notada para um público? Mais do que isso, deveríamos indagar: como a publicidade torna a mensagem "digna de credibilidade", credibilidade que pode certificar os seus próprios produtos? Falar-nos na intimidade, sobre aquilo que nos interessa, ou da forma que nos interessa que, de antemão, desperta a nossa atenção, para nos tornarmos sensíveis a sua mensagem, é um dos seus principais ardis.

Insuspeitas, mas não menos notórias, são as relações que se podem traçar entre a publicidade e a chamada pop art, dos anos 60. Se esta provocou o deslocamento do olhar (a assimilação da pop art ao aspecto da reprodutibilidade já havia sido anunciada pela fotografia), conduzindo-nos de volta à cotidianidade dos objetos que nos cercam, em toda a sua objetualidade, comunicando-nos a perda da aura dos objetos artísticos (BENJAMIN, 1982), provocou, com essa mudança de foco, o modo de se fazer notar da arte, quando subverte a capacidade daquilo que entendemos como o fazer artístico. Como coloca Ferrara (1986):

Uma produção pop é um verdadeiro inventário da cultura de massa: produção em série, consumo, efemeridade. Objetos materiais ocupam a tela envolvendo o receptor e executando dupla função: a primeira é atraí-lo pelo reconhecimento, na tela, dos mitos que povoam o seu cotidiano; a segunda é trazê-lo para o universo da obra esvaziando, com isso, o significado daqueles objetos e materiais rotineiros que, por estarem fora do seu universo habitual, perdem a familiaridade que os envolvem. Logo, na arte pop, os objetos e materiais de consumo exercem a dupla função de atrair e provocar o estranhamento do receptor. (grifo nosso)

Da mesma forma ocorreu com a publicidade, na medida em que ela:

nos seus melhores exemplos, parece baseada no pressuposto informacional de que um anúncio mais atrairá a atenção do espectador quanto mais violar as normas comunicacionais adquiridas (e subverter, destarte, um sistema de expectativas retóricas) (ECO, 1991, p. 157) 
Estendendo o que diz Ferrara (1986) sobre pop art à linguagem da publicidade, podemos dizer que, em um primeiro momento, esta linguagem, e também a da pop art, atrai o receptor pela identificação com algo, a princípio familiar, por meio de linguagens que lhes dão suporte.

Enquanto a pop art "esvazia o significado" dos objetos, ao dar-lhes novos significados, em função do deslocamento do olhar que eles provocam no novo contexto em que são colocados, a publicidade "substitui" o sentido dos objetos anunciados, na medida em que eles deixam de ter um valor utilitário, quando lhes são acrescentados valores outros (status, poder, masculinidade, feminilidade etc.) que "devem ser conquistados" com a aquisição dos bens consumíveis que são ressignificados com esses valores.

Esvaziado o objeto de seu caráter utilitário, perde-se o nexo que o justifica para a demanda de mercado, desaparecendo, com isso, sua finalidade prática. Se a demanda não existe - porque a publicidade não sabe exatamente das reais necessidades dos consumidores - ela cria essa demanda em função dos valores por meio dos quais procura atingir seu interlocutor: valores "familiares", pelo desejo (de uma classe) que pretende suscitar e pela forma pela qual a mensagem publicitária é veiculada (recursos de linguagens comuns para o público: imagens, sons (músicas) e expressões lingüísticas conhecidas).

\section{A linguagem na publicidade}

A intencionalidade guia a construção do texto publicitário. Considerando-se a "imagem" que se faz do receptor, a intencionalidade é sempre a condição para que a própria linguagem, em que é veiculada a mensagem publicitária, seja entendida e assimilada. Por isso, a linguagem que a ele se destina é burilada e medida, a fim de que seja não apenas o vínculo que o liga ao produto ou serviço, mas também que seja, em um primeiro momento, "consumida", para que possa servir, antes, como um vínculo entre ambos (CHAMARELLI FILHO, 1998).

Como exemplo, poderíamos citar a publicidade da Porto Seguros, que diz: Você não pára de pensar na sua casa própria? Nós também não. Lida-se aqui com o fato de a publicidade "saber" que a aspiração da maioria dos brasileiros é a compra da casa própria, por isso, o consumidor aqui visado é aquele que almeja comprar um imóvel ou pretendente adquirir meios para comprá-lo.

Considere-se ainda, nessa mesma publicidade, o fato de que há uma expressão muito utilizada na fala coloquial, qual seja, "não pára de pensar", que pode evocar uma certa familiaridade lingüística com o leitor, a fim de que o mesmo também possa, em um primeiro momento, familiarizar-se, logo, identificar-se com a linguagem que a ele é dirigida.

Como forma de chamar a atenção desse leitor, a utilização da expressão "não parar de pensar", presente na questão que se coloca diretamente para "ele", consumidor em potencial de produtos e de mensagens, o conduz à busca de uma satisfação que poderá ser alcançada, a princípio, no campo da linguagem.

A pergunta feita a ele, consumidor, constitui-se, então, como meta a ser atingida em curto prazo, já que o caráter efêmero da própria publicidade demanda uma assimilação rápida da mensagem e de seu conteúdo. É a essa demanda que a própria Porto Seguros pretende atender, por meio da oração: Nós também não [paramos de pensar na (sua) casa própria] ${ }^{2}$.

\footnotetext{
${ }^{2}$ Acompanhando a construção da primeira oração da publicidade, admite-se que o trecho entre colchetes possa estar subentendido, por paralelismo sintático.
} 
Por que então a Porto Seguros "não pára de pensar na (nossa) casa própria", já que somos nós, presumivelmente, os interessados por tal produto, poder-se-ia perguntar? Porque é ela quem poderá cessar esse "desejo" que nos incomoda "continuamente", ou seja, adquirir a casa própria.

A estratégia desenvolve-se aqui no sentido de o leitor aceitar a inferência que pode ser produzida, a partir do seguinte pressuposto: "você não pára de pensar na casa própria", e encadear sobre esse pressuposto ${ }^{3}$ o argumento de que o ato que ele, consumidor, possivelmente realiza é objetivado também por quem, na condição de lhe fornecer meios para a aquisição da casa própria, é também sensível a um mesmo tipo de inquietação: Nós também não [paramos de pensar na (sua) casa própria]. Fato que, a princípio, identifica consumidor à empresa Porto Seguros. Identificação que os coloca, supostamente, na mesma condição, já que são passíveis de terem a mesma preocupação: "não parar de pensar na casa própria".

Outro exemplo muito interessante diz respeito à função do texto na publicidade da mineradora Samarco ${ }^{4}$, cuja produção é assinada pela agência Lápis Raro, de Belo Horizonte. Apesar de o texto ser quase todo referencial, essa publicidade utiliza recursos de estilos, como se verá a seguir, que extrapolam o escopo do quadro comumente admitido para a classificação dos textos escritos ${ }^{5}$, porque lida com a capacidade de percepção e de ordenamento cognitivo dos leitores. A idéia de "transformação", sugerida pela publicidade, pode ser observada pela convergência das mensagens icônicas e visuais: tanto pela disposição das palavras (cf. esquematização abaixo) como pelo arranjo linear das pelotas de minério de ferro (cf. figura 1) ${ }^{6}$. Assim:

$$
\begin{aligned}
\text { SONHO } & \rightarrow \text { IDÉIA } \\
\text { IDÉIA } & \rightarrow \text { INOVAÇÃO } \\
\text { SAMARCO (INOVAÇÃO) } & \rightarrow \text { REALIDADE }
\end{aligned}
$$

A intenção da publicidade, como se pode observar, é dar uma idéia de transformação e o que ela implica, em função do quê. Transformação esta que não apenas modifica palavras, mas "conceitos", fazendo com que, ao signo SAMARCO, some-se um novo conceito. Pode ser depreendida a seguinte "linha de raciocínio":

$$
\text { REALIDADE }>\text { SAMARCO }>\text { INOVAÇÃO }>\text { IDÉIA }>\text { SONHO }
$$

que, por sua vez, "em ordem" seria:

$$
\mathrm{SONHO} \rightarrow \text { IDÉIA } \rightarrow \text { INOVAÇÃO } \rightarrow \text { SAMARCO } \rightarrow \text { REALIDADE }
$$

\footnotetext{
3 Segundo Ducrot (1977), uma vez admitido o pressuposto, pode-se encadear sobre ele. Ou seja, dar prosseguimento ao discurso, a partir do que foi admitido como válido, entre os interlocutores.

${ }^{4} \mathrm{O}$ texto dessa publicidade foi observado, primeiramente, na revista em que foi publicado. A imagem reproduzida na figura 1 foi copiada do site da SAMARCO MINERADORA. Alertamos os leitores que a imagem é a mesma.

${ }^{5} \mathrm{O}$ quadro das funções da linguagem, segundo Jakobson.

${ }^{6}$ Essa idéia de "transformação" é redundante no entrelaçamento das mensagens icônico-visuais, repetindo-se no conteúdo do texto. Observe-se a utilização de alguns verbos do texto (fazer, gerar, criar), dando a noção de uma produção que transforma. A idéia de "transformação" é reforçada pelas pelotas, colocadas da esquerda para a direita, mas também pela mensagem: "A Samarco é uma empresa brasileira fornecedora do minério de ferro que ajuda a mover o mundo".
} 
CASA, Vol.4, n.2, dezembro de 2006

Que elemento faz a ponte entre sonho e realidade?

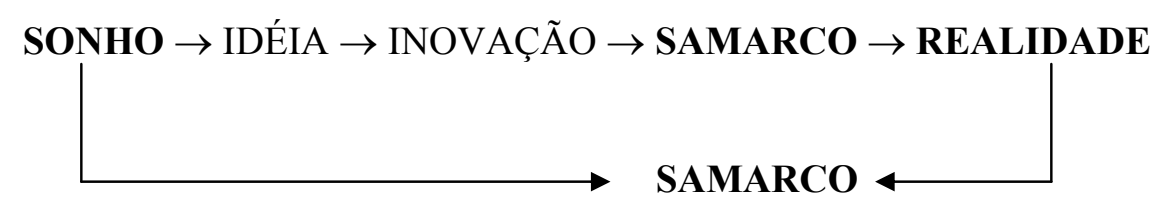

A "transformação" sugerida converge para a imagem das pelotas de minério (colocadas nas mãos, em forma de concha), no texto, no canto direito da página (cf. figura 1), e nas circunferências cuja leitura em direção à seta $(\rightarrow)$ é "para direita".

Pode-se assim entender a publicidade: o minério sofre uma transformação. Samarco é quem faz essa tranformação ("mover o mundo"). A seta indica o processo de transformação, além das várias graduações das circunferências. A Samarco é quem faz virar realidade o sonho de mover o mundo.

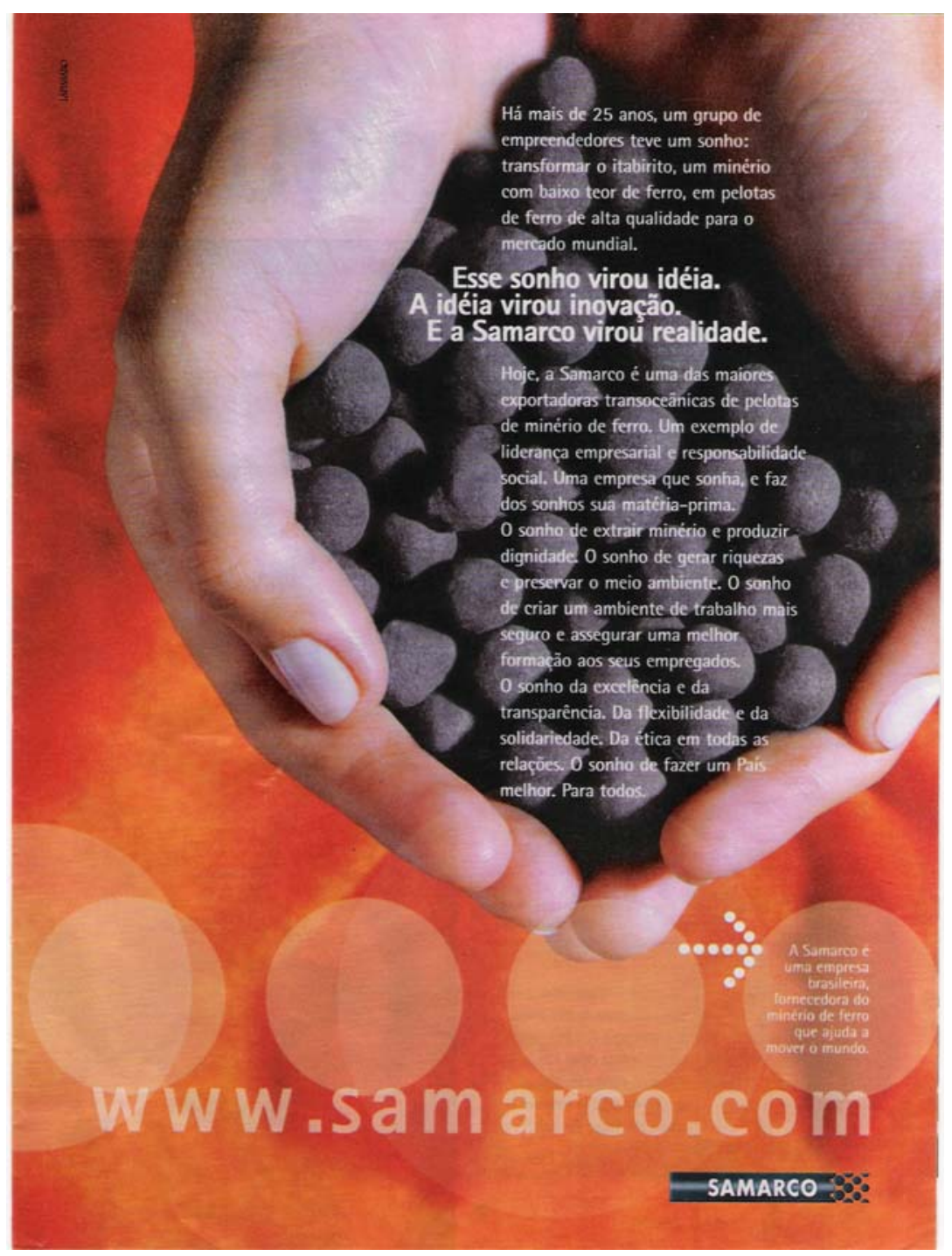

Figura 1 - Publicidade da Mineradora Samarco (Agência Lápis Raro) 
Para efeitos de análise dos textos publicitários, devemos levar em consideração não apenas a relação direta entre um anunciador e um receptor de publicidades, em uma relação unidirecional pela linguagem. $\mathrm{O}$ esquema, que reduz o ato de linguagem à presença de um emissor e de um receptor, herdado da teoria da informação (ademais, como a própria designação dos termos pelos quais se coloca a polaridade do evento comunicativo), torna-se inoperante, porque o ato de fala, o que o envolve e os "efeitos de sentido" que dele decorrem, supõe uma complexidade muito maior do que a prevista pela esquematização de Jakobson ${ }^{7}$.

Segundo Charaudeau (1982), há não apenas dois elementos, mas quatro "protagonistas", envolvidos no ato de comunicação (Jec, Jee, Tud e Tui), instâncias, portanto, que são constituídas no ato de linguagem. Uma vez instaurados, os protagonistas do ato de linguagem se submetem às condições que envolvem este tipo de ato. Para cada tipo de ato comunicativo, há restrições daquilo que deve ser dito, como deve ser dito, e quem estará em condições de dizê-lo ou de recebê-lo; por isso fazem parte de um "contrato de fala" ${ }^{\text {. }}$. Esse contrato se estabelece em função das seguintes condições:

eles se atribuem um certo estatuto psicossocial, sendo que cada um desses estatutos é imaginado por cada um dos protagonistas;

eles estabelecem entre si um contrato de troca que é da ordem do Fazer, e não do Dizer, e que depende do status psicossocial (relação de poder/submissão);

eles são dependentes do canal físico de transmissão (oral, gráfico, direto/ difundido) (CHARAUDEAU, 1982, p. 5. Tradução nossa).

Ou seja, a publicidade, em função da sua argumentação, almeja levar aquele que a recebe a um fazer, a um comprar. A relação contratual vai além daquela de um cumprimento, conforme o nome "contrato" poderia assim sugerir; é uma relação daquilo que pode ser admissível sem consentimento, em uma relação de uma suposta simples troca. As trocas linguageiras, que se dão no cotidiano, assumem esse caráter natural, e é dessa naturalidade que a publicidade pretende se apropriar, colocando-se como mediadora, na relação produtopúblico, por intermédio da linguagem, dos atos de linguagem.

Consideremos as seguintes instâncias que se constituem no ato de linguagem e que o fundamentam, segundo Charaudeau (1982, p. 6):

\footnotetext{
${ }^{7}$ Não é tarefa deste trabalho fazer o levantamento das conjecturas em torno das críticas ao esquema então mencionado.

${ }^{8}$ Embora em uma instância mais restrita, devamos estender os contratos de fala, "contrat de parole", segundo a terminologia de Charaudeau (1982), à mesma função que Ducrot destina à língua, ao entendê-la como um quadro que regula as práticas sociais entre os indivíduos (cf. DUCROT, 1977).
} 


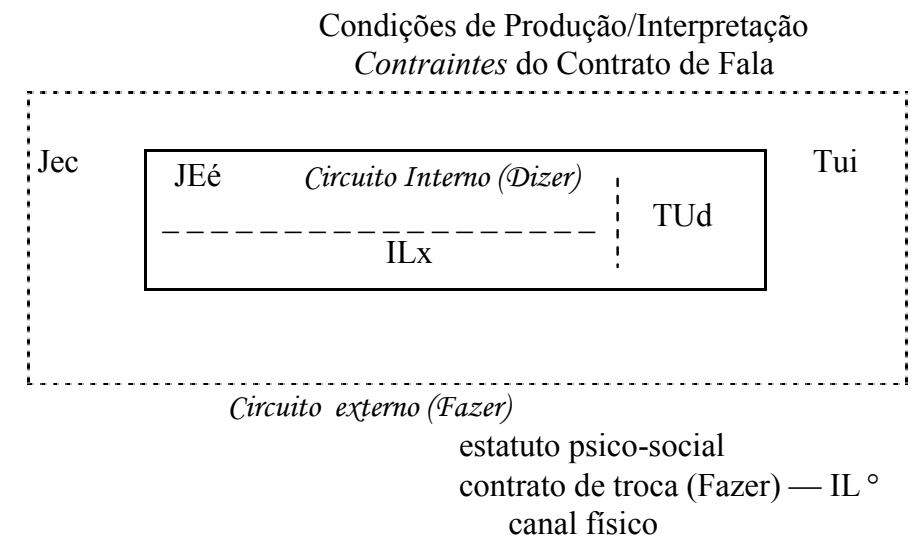

Figura 2 - Instâncias constitutivas do ato de linguagem

Em que:

Jec: o indivíduo real, o sujeito comunicante cria um Jee: sujeito enunciador, que é um "sujeito da palavra". É ele que é responsável pelos efeitos que o uso da linguagem pode ter sobre o sujeito interpretante (leitor ou ouvinte). $\mathrm{O}$ Jee cria/fala/escreve para um

Tud: sujeito interpretante (destinatário) ideal. O objetivo de Jec/Jee é fazer com que as interpretações deste destinatário ideal coincidam com as do destinatário real, o

Tui: sujeito interpretante real, exterior ao texto, ao circuito interno da palavra.

Finalmente,

Ilx: representa o "mundo" falado/contado no circuito interno, um mundo que tem a pretensão de ser um testemunho do

II $^{\circ}$ : mundo real. ${ }^{9}$

Em linhas gerais, pode-se exemplificar, a partir do esquema acima que Jec (a agência de publicidade que produz o texto publicitário) cria uma imagem de um enunciador de publicidade (o enunciador). Essa imagem deve equivaler à imagem que o público (Tui) faz ou almeja fazer desse enunciador (Tud). No momento em que as imagens de Tud e Tui convergem, há uma identificação entre aquilo que a agência sugere, como imagem de um enunciador, e aquilo que o público imagina, como a sua imagem projeta nesse enunciador.

Por exemplo, no anúncio dos xampus da marca Seda: "Fivelas escorregam em cabelos lisos. Homens grudam", a imagem que Jec (Agência) propõe é a de um enunciador (Jee) que possui cabelos lisos e que sugere que a imagem projetada de Tud em Tui seja aquela de uma mulher que deseja ter cabelos lisos ou mais lisos, gerando assim um anseio de identificação da consumidora (Tui), em função do "valor" que é agregado ao possível benefício do produto: "a conquista dos homens". O efeito desejado pela publicidade é obtido pela antítese: fivelas $\rightarrow$ escorregam $v s$. homens $\rightarrow$ grudam. Note-se que, a partir dessa oposição, o verbo "grudar", que em geral tem conotação negativa, passa a ter, nesse contexto, conotação positiva.

\footnotetext{
${ }^{9}$ Segundo Machado (1995), tomando por base a teoria semiolingüística, de Patrick Charaudeau.
} 
Essa identificação é necessária para o êxito da publicidade. Nesse momento, convergem as imagens de Tud e Tui; a consumidora (Tui), identificada em seus anseios possíveis, passa desejar em função de

— um certo produto $(\mathrm{P})$, [que] graças às suas qualidades positivas $(\mathrm{q}+)$, proporciona um resultado benéfico $(\mathrm{R}+)$;

- Você tem uma falta que não pode não querer preencher;

- ora, se o que esse produto proporciona $(\mathrm{R}+)$ representa precisamente o preenchimento de sua falta, é porque ela deve tornar-se objeto de sua busca;

- ora, é graças a $(\mathrm{P})$ que se pode obter $(\mathrm{R}+)$; ou seja, $(\mathrm{P})$ representa o auxiliador facilita a procura - de sua busca. (CHARAUDEAU, 1982 e 1983, p. 9 Tradução e grifo nossos)

Na publicidade de Seda, $\mathrm{P}$ corresponde ao xampu Seda; $\mathrm{q}+$ ao beneficiamento dos cabelos e R+ consiste no resultado, que vem a ser "deixar os cabelos lisos". É por intermédio das qualidades que o xampu Seda apresenta que a leitora-interlocutora conseguirá deixar os cabelos lisos, atingindo, assim, a satisfação de sua busca.

\section{Imagem e recepção das publicidades}

Como vimos acima, dentro de uma "criação de identidade" entre público e produto, a publicidade lança perguntas e a elas responde. Muitas vezes, a pergunta é respondida pela imagem do produto. Esse é apenas um dos muitos recursos que a publicidade utiliza na criação de seus textos. Observemos um exemplo.

$\mathrm{Na}$ publicidade original da Loção Solar Protetora Nívea ${ }^{10}$ (cf. figura 3), o texto colocado, ao lado da modelo fotografada, é: "Sabe qual é a moda na praia neste verão?" Para obter a resposta a essa indagação, deve-se passar, primeiro, pela visualização da imagem de uma mulher, até chegarmos ao produto, utilizando o procedimento tradicional de leitura em "Z".

Naturalmente que esse tipo de leitura é previsto pelo publicitário, na medida em que lida com a forma de varredura que fazemos de um texto, na cultura ocidental.

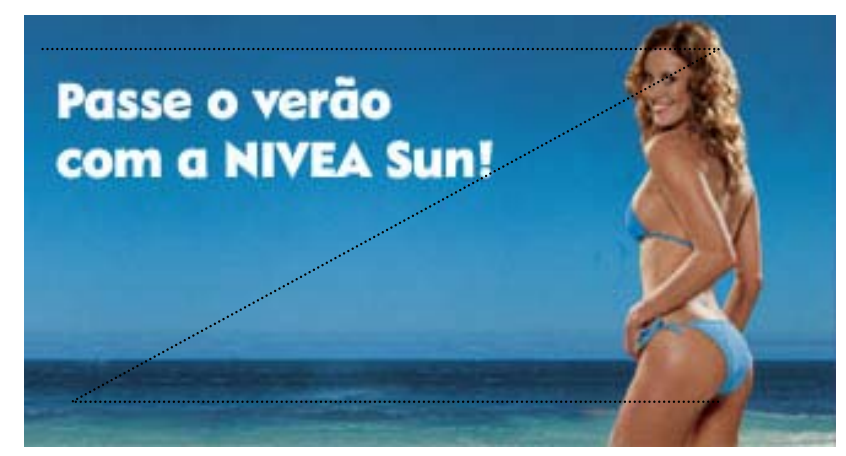

Figura 3 - Publicidade de Loção Solar Protetora Nívea.

\footnotetext{
${ }^{10}$ No site da marca Nívea, de onde a publicidade foi retirada, não consta a imagem do produto, originalmente localizado no canto inferior direito, ao lado das nádegas da modelo. O texto também é diferente do apresentado na publicidade da revista.
} 
O conhecimento de mundo do leitor/espectador é levado em consideração, quando a publicidade "cita" imagens de seu universo cultural ${ }^{11}$. Esta citação, que não deixa de ser uma "apropriação", pode ser feita de diferentes maneiras e com diferentes intenções. Por exemplo, a publicidade "Glamour" de O Boticário, "cita" uma cena do filme Beleza Americana, ao colocar no texto uma mulher rodeada de frascos de perfumes como se fossem pétalas de rosa.

Muitas vezes, as imagens tomadas emprestadas da cultura ocidental e utilizadas em publicidades, ganham uma outra leitura, podendo servir, ao mesmo tempo, como "argumentos de autoridade", na medida em que deslocam uma figura clássica para uma peça publicitária, como também podem servir a paródias, como, por exemplo, no caso da figura de Monalisa, de Leonardo D'a Vinci, que já apareceu em revistas, transfigurada como uma outra mulher, usando óculos da marca Ray-ban, usando aparelho odontológico e até como a personagem Mônica, criada por Maurício de Sousa.

A utilização dos recursos acima mencionados diz respeito a um reporte aos imaginários sócio-culturais dos leitores/espectadores, a fim de que a peça publicitária possa servir, como elemento de identificação para com esses espectadores, e que possa, por conseqüência, ser avaliada, a partir de uma legitimidade, ou de uma transgressão permitida dessa legitimidade.

A última tendência nas publicidades de revistas é a interatividade ou a simulação de "brindes", acoplados nas próprias páginas das revistas. A proposta atual dessas publicidades é fazer com que o leitor interaja com elas, conferindo-lhe um caráter mais privativo, ao fazer dele alvo da mensagem que lhe é destinada, e também mais "curioso", na medida em que algo está não somente escondido, mas oculto em um objeto que pode ser visto por todos, no interior de uma revista.

Ao interagir com esse tipo de publicidade, o leitor torna-se seu co-autor, seu criador. Essa "criação" se dá pelo desvelamento do produto "escondido", que se dá a conhecer, no momento em que o leitor viola o lacre do "brinde" que lhe é fornecido pela revista. A função das ações naturais é aqui deslocada, ou seja, não se interage para criar, mas para se deixar persuadir.

\section{Comportamento e marca}

Para o produto ser desejado, tem que "suscitar desejos" ou despertar desejos latentes, mesmo que eles não venham a ser satisfeitos da forma como a publicidade os idealiza. Mais explicitamente coloca a publicidade do Honda Civic: "Muito mais que um meio de transporte. É um meio de ficar feliz" (grifo nosso). Nesse caso, o automóvel é não apenas o veículo ou meio de transporte - como sua característica mais peculiar é a menos enfatizada pela publicidade - é o meio para se alcançar a felicidade.

Apesar dessas observações, arriscaríamos dizer que a publicidade não pretende "vender verdades", ou antes, objetos, mas formas de comportamento, de desejar. É na esfera do desejo que nasce "o sonho de consumo". O meu sonho de consumo é... algo "proibido" como meta de algo que em curto prazo não pode ser realizável, algo para o qual, entre mim e ele, se interpõem desejos, desejos que se encontram com outros desejos e gostos de uma mesma classe, a quem são destinados determinados tipos de arquétipos. Como nos diz Eco (1991, p. 157):

\footnotetext{
${ }^{11}$ Não serão mostradas figuras que exemplifiquem os próximos exemplos, tratados nesta parte do trabalho.
} 
Existe, é fato, um tipo de excelente comunicação publicitária que se baseia na proposta de arquétipos do gosto que preenche exatamente as mais previsíveis expectativas, oferecendo, por exemplo, um produto feminino através da imagem de uma mulher pela sensibilidade corrente.

O arquétipo, nesse caso, é a forma que julgamos ideal para que possamos nos assumir como membros de uma determinada classe e com ela ser identificado.

$\mathrm{Na}$ instância das formas de comportamento suscitadas pela publicidade, encontramos exemplos claros nos textos da Benneton e da DuLoren. Num exemplo desta última, a publicidade diz o seguinte: Você sabe do que uma DuLoren é capaz? Nas publicidades dessa marca, o desafio lançado às consumidoras, ao mostrar cenas audaciosas, é assumido pela própria marca. Não é o produto da DuLoren que deve ser responsável por qualquer tipo de comportamento extraordinário, efetivo ou não, a ser despertado pelo produto é a própria publicidade que é capaz de se propor audaciosa o mais do que suficiente para subverter a capacidade "média" da imaginação (também presumida pela publicidade) das consumidoras, para lançá-las ao desafio de usar a marca e tornarem-se "aptas" a experimentarem desejos de algo que está, presumivelmente, en-coberto.

A "roupa debaixo", o sous-vêtement, que desperta desejo, é a "segunda pele". A função de embelezar o que já é por si só belo é encontrada aqui também, tal como encontramos na publicidade dos cremes de beleza, xampus, etc. Todos vêm para revigorar, transformar, em suma, atuar em profundidade como coloca Barthes (1991, p. 58-60) para a atuação dos detergentes, que agem, por esse aspecto, não de forma diferente de xampus, cremes, loções de beleza ${ }^{12}$.

Este tipo de comportamento só se efetiva porque a publicidade já se sabe conhecedora do seu poder: a sua credibilidade. Como diz Veron (1991, p. 168), ao interpretar Michel de Certeau, as "mídias, às quais eu sou fiel, são aquelas nas quais eu deposito a minha crença".

\section{Considerações Finais: a Credibilidade pela Linguagem}

À medida que aumenta o poder de persuasão da mídia em geral, por intermédio dos recursos gráficos, crescem, por outro lado, as possibilidades de escolha de quem "recebe" a mensagem. Dentre as milhares de mensagens veiculadas por revista, televisão, cartaz, outdoors, internet etc. como atingir um consumidor? Sem dúvida, mais do que nunca, o consumidor é o alvo e, como tal, precisa ser diferenciado do grande público que não tem acesso à maioria dos bens de consumo, expostos pela publicidade.

É por meio da identificação (verbal-vocal-icônica,) e, portanto, da intimidade proposta ao consumidor, que a publicidade entra no aconchego dos nossos lares. Ela se permite entrar, não porque seja arrogante, mas porque, ao simular uma interlocução com 0 leitor/telespectador/consumidor, por meio de músicas, textos e imagens, traz consigo o passaporte da intersubjetividade.

\footnotetext{
${ }^{12}$ A propósito: o corpo é objeto de culto e exposição, pela publicidade, por isso, ele tem de ser tratado como tal, como algo visível. Meio e fím dos produtos a que ele se endereça: o corpo torna-se sempre um objeto a ser transformado. À imagem do corpo, agrega-se o valor do benefício do produto, que só pode ser obtido com a aquisição do produto anunciado.
} 
Ao simular uma espécie de diálogo, a publicidade coloca-nos na condição de interlocutores da mensagem que a nós se destina. A naturalização da qual essa mensagem se reveste é, nesse momento, o passaporte para que possamos estar, a princípio, suscetíveis de recebê-la. Porque o princípio que guia o seu direcionamento é o da simulação da troca linguageira, a partir das condições que pretendem fazer dessa troca um ato "natural", fazendonos supor sempre a presença de um "outro" a quem nos dirigimos ou que se dirige a nós.

Fundamentada na constituição do princípio dialógico da linguagem, a simulação publicitária reconhece o seu princípio de constituição, qual seja, estar na condição de locutorário de um ato de linguagem é, implicitamente e imediatamente, identificar alguém na posição de alocutorário $^{13}$. O princípio, reconhecido então como natural, constitui-nos como sujeitos de fato, da mensagem publicitária, na medida em que nos colocamos na condição de alocutários da mensagem que a nós é destinada, por um locutário.

Ao se dirigir a nós, ainda que supostamente não nos conheça (o público), a publicidade simula uma relação que é natural, em nosso cotidiano, situação por meio da qual a reversibilidade de que fala Benveniste, entre os pronomes "eu" e "tu" (ao tratar da subjetividade na linguagem), assume um caráter espontâneo, colocando-nos sempre na condição de saber que podemos dizer, que podemos retrucar, enfim, que podemos dialogar. Mas a resposta, nesse caso, ultrapassará o âmbito da troca, pois ela só poderá se efetivar como um comportamento que foi suscitado pela linguagem - e também, por que não dizer, pela imagem - e para o qual "se deve" responder. Parece-nos que o trecho a seguir será suficientemente claro para explicar o que dissemos acima: "A relação com o enunciado do outro não pode ser separada nem da relação com a coisa (que é objeto de uma discussão, de uma concordância, de um encontro) nem da relação com o próprio locutor" (BAKHTIN, 1992, p. 351).

Ainda que a linguagem e a imagem existam aqui como efeito do ato que as coloca no espaço de simulação de uma troca dialógica, é por seu intermédio que respondemos (como assimilação da própria linguagem/imagem ou como compra de um produto) a quem nos fala, na intimidade.

\section{Referências Bibliográficas}

BAKHTIN, M. Os gêneros do discurso. In: Estética da criação verbal. São Paulo: M. Fontes, 1992.

Problemas da poética de Dostoiévski. Rio de Janeiro, Forense Universitária, 2002.

BARTHES, R. A retórica da imagem. In: O óbvio e o obtuso. Lisboa: Edições 70, 1984.

Mitologias. São Paulo: Bertrand Brasil, 1993.

BENJAMIN, W. A obra de arte na época de sua reprodutibilidade técnica. In: LIMA, L. C.

(Org.) Teoria da cultura de massa. Rio de Janeiro: Paz e Terra, 1982.

BENVENISTE. E. O aparelho formal da enunciação. In: Problemas de lingüistica geral II. Campinas: Editora da UNICAMP, 1989.

\footnotetext{
${ }^{13}$ Conforme pode ser observado em Benveniste (1989, p. 84.
} 
CASA, Vol.4, n.2, dezembro de 2006

CHABROL, C. Le lecteur: fantôme ou realité? Étude des processus de réception. In: CHABROL C., CHARAUDEAU, P. Lecteurs cible et destinataires visés. A propos de l'argumentation publicitaire. In: VS n ${ }^{\circ}$ 52/53, Bologne: Bompiaini, 1989. p. 151-161.

CHAMARELLI FILHO, M. A constituição de publicidades em publicidades televisivas: uma abordagem semiolingüística. 111 f. Dissertação (Mestrado em Lingüística) Universidade Federal de Minas Gerais, Belo Horizonte, 1998.

CHARAUDEAU, P. Éléments de sémiolinguistique d'une théorie du langage à une analyse du discours. In: Connexions $n^{\circ} 38$, Paris: ARIP-EPI, 1982. p. 7-30.

La presse produit production. Paris: Didier Éruditions, 1988. p. 161-184.

DUCROT, O. Princípios de semântica lingüística. São Paulo: Cultrix, 1977.

ECO, U. A estrutura ausente. São Paulo: Perspectiva, 1991.

FERRARA, L. D’A. A estratégia dos signos. São Paulo: Perspectiva 1986.

JAKOBSON R. Lingüística e comunicação. São Paulo: Cultrix, 1988.

MACHADO, I. L. A ironia como fenômeno lingüístico-argumentativo. In: Revista de Estudos Lingüísticos. Belo Horizonte, ano 4, v. 2, p. 143-155, jul./dez. 1995.

ROCHA, L. M. de Carvalho. Uma proposta de mensuração do envolvimento do consumidor. 97 p. Dissertação (Mestrado em Administração) - PUC/ Rio de Janeiro, 1988.

VERON, E. Les médias em réception: les enjeux de la complexité. In: Medias Pouvoir, Bayard Press, $n^{\circ} 21$, fevrier, mars, 1991. 